\title{
China's exchange rate policy, its current account surplus, and the global imbalances ${ }^{1}$
}

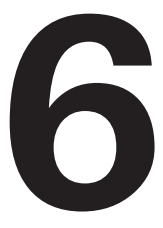

W. Max Corden*

This chapter is stimulated by current views prevalent in the United States about Chinese exchange rate policy. The Chinese currency, the Renminbi (RMB for short), was fixed to the US dollar from 1997 to 2005. In July 2005 a new regime was instituted, and from then on there was some appreciation of the RMB-dollar rate. It appreciated cumulatively about 9 per cent by the end of 2007. In general, US critics have not considered this appreciation as being sufficient. The common argument was that, if the RMB were allowed to float, it would appreciate substantially more, and this would reduce China's high current account surplus as well as the US deficit. In this view the Chinese exchange rate regime and policy within the regime have been (more or less) the causes of the current account imbalance. It is implied that the Chinese exchange rate intervention caused the Chinese current account surplus and at least played a role in causing the overall US current account deficit. ${ }^{2}$

Table 6.1 shows the Chinese current account surplus as a percentage of GDP from 2000 to 2008. Of course, these figures give the overall Chinese surplus and not just the bilateral surplus with the United States.

\section{Table 6.1 China: Surplus on Current Account, per cent of GDP}

\begin{tabular}{l|l|l|l}
\hline 2000 & 1.7 & 2005 & 7.2 \\
\hline 2001 & 1.3 & 2006 & 9.5 \\
\hline 2002 & 2.4 & 2007 & 11.0 \\
\hline 2003 & 2.8 & 2008 & 10.0 \\
\hline 2004 & 3.6 & & \\
\hline
\end{tabular}

Source: International Monetary Fund, World Economic Outlook, April 2009.

* (C) The Royal Economic Society 2009. This paper appears in the Economic Journal volume 119 issue 541 and is printed here with permission of the Royal Economic Society. 
Until 2005 China was criticised for fixing the value of the RMB to the US dollar. After that it was criticised for not allowing the RMB to appreciate enough. But the real objection was clearly to the large current account surplus, rather than to a fixed exchange rate per se. After all, fixing an exchange rate to the dollar was common under the Bretton Woods system, and even after the general breakdown of this system some countries (notably in Latin America) fixed their exchange rates to the dollar without any complaints from the United States. Furthermore, there are no International Monetary Fund rules that prohibit this. Similarly there can be no good objection to some intervention in the foreign exchange market. Many countries have exchange rate regimes that involve some management or "manipulation".

Section 1 of this paper discusses the relationship between exchange rate intervention and the current account outcome in the chinese case. Section 2 discusses the possible reasons or justifications for Chinese policies and developments that have led to this outcome. Finally, Section 3 deals with the implications for other countries, particularly the United States, of China's current account surplus and of China's growth. This discussion includes some reflections on how Chinese surpluses have been related to the current world credit crisis. Is China to blame?

This chapter is written in memory of James Meade, whose student I was in the fifties. Inevitably I have absorbed his taxonomic approach, and therefore will expound various alternative views or positions.

\section{The role of the exchange rate and other factors in determining China's surplus}

\section{Many kinds of exchange rate regimes are compatible with a current account surplus}

It might be argued that exchange rate regimes are not really connected with global current account imbalances. Global current account imbalances have been associated with all kinds of exchange rate regimes. Spain has a large deficit while the Netherlands has a surplus. Yet both have a fixed exchange rate to the Euro, i.e. they are both part of the Eurozone. Of course, the Euro itself floats relative to the principal non-Euro currencies. In the nineteen eighties the US current account deficit and the Japanese surplus were the main international imbalances, and Japan certainly had 
to suffer continuous criticism from the United States. Now, again, Japan is one of the major surplus countries and, as usual, the United States is the major deficit country. Yet both the United States and Japan have floating rate regimes; and in the case of Japan there is only occasional intervention. Thus a floating rate regime between them is obviously no inhibition to a current account imbalance.

Suppose a country has a floating exchange rate regime with no intervention in the foreign exchange market at all. Nevertheless its government wishes to induce a current account surplus, with the accompanying depreciation of the exchange rate. This is certainly possible if there is international capital mobility. The government can loosen monetary policy and so induce capital outflow through the lower domestic interest rate. Alternatively, it can contract fiscal policy, leading to a reduced budget deficit and thus, again, a lower domestic interest rate and thus depreciation, capital outflow, and, again, a current account surplus. In both cases exchange rate intervention is not needed to bring about a current account surplus. But this argument does not apply to China because capital outflows are strictly controlled, as is the interest rate.

\section{Why did China's current account surplus increase?}

How then does the system work in China? What determines the current account balance? In particular, why did the current account surplus increase so sharply from 2005 (see Table 6.1)? The diagrammatic exposition in the next section is my attempt at a stylised story. There are two essential points. The first is that the current account balance has not been planned by the central authorities but rather has been an unplanned by-product of a variety of developments and policies. Exchange rate policy, as reflected in intervention in the market, has just been one part of the story. Hence the remarkable increase in the surplus from 2005 (as shown in Table 6.1) was not necessarily intended by central policy-makers. The second point is that exchange rate policy can and does affect the surplus: if it were desired to reduce the surplus a policy that brought about significant real appreciation could achieve it. But, in practice, exchange rate policy has been targeted on another objective, which I shall discuss.

Where did the sudden rise in the surplus from 2005 come from? First, let me summarise the point of view of Anderson (2008). In this view, which actually tells only one part of the story, "the main shock was a dramatic fall in import growth." (Anderson, p. 62). The turn around "came almost 
completely from net trade in heavy industrial products (aluminium, machine tools, cement, key chemical products, and especially steel and steel products)". This was the result of an earlier domestic investment boom in that category of products, which, in turn, was stimulated by an earlier rise in domestic demand for such products. At the same time, between 2002 and 2006 national savings increased by more than 10 per cent of GDP. This, in turn came from the corporate sector, and especially in the heavy industrial sector. Anderson gives more details, but his main point is that the increased current account surplus resulted from a combination of a rise in the excess of savings over investment, and a decline in the growth rate of imports, both originating in a particular sector of the economy.

Figure 6.1 China's merchandise trade, 2000-2007 (US billion)

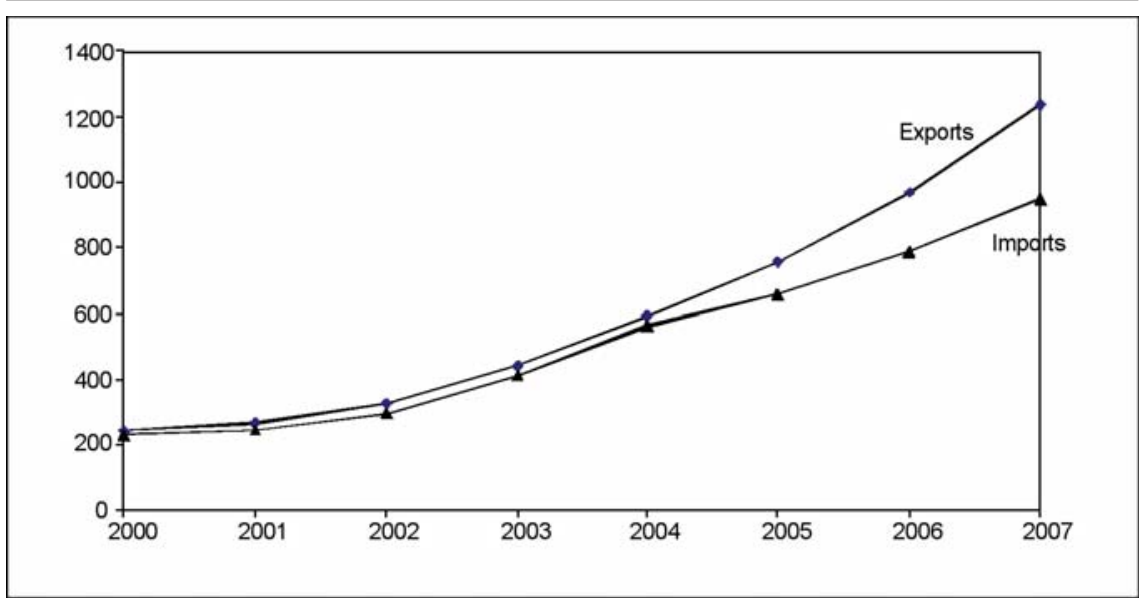

Source: Based on Data compiled from UN Comtrade database.

Yet there have also been other factors. ${ }^{3}$ The overall picture is that there has been both an acceleration of the rate of growth of exports and a decline in the rate of growth of imports. This is shown in Figure 6.1. The average annual rate of growth of exports increased from 23.8 per cent (2000-2004) to 26.3 per cent (2005-2007), while the average annual rate of import growth declined from 26.3 per cent (2000-2004) to 19.8 per cent (2005-2007). There have been steady productivity improvements in the labour-intensive exports sector. Furthermore, as is pointed out in Athukorala (2009), in 2002 China joined the World Trade Organisation (WTO) and this significantly improved the attractiveness of China's domestic investment climate for export-oriented production. Consequently the process of relocation to China (from Japan, Taiwan and Korea especially) of final 
assembly activities of information and communication technology products accelerated. This showed up in the export statistics with a time lag.

\section{How it all fits together: A diagram}

Allowing for considerable over-simplifications, the Swan diagram (from Swan,1963) is helpful, especially in illustrating the sharp increase in China's current account surplus. It is a diagrammatic summary of one of the main messages that originated in James Meade's classic The Balance of Payments (1951).

In Figure 6.2 the vertical axis shows an index of China's competitiveness. An upward movement can be brought about by a real depreciation, or by an improvement in productivity in export and import-competing industries. As I have noted, there have been steady productivity improvements in labour-intensive exports. In addition, on the import-competing side, one can regard the expansion of heavy industrial product industries, as highlighted in the Anderson story, as also being a productivity improvement. As noted above, WTO accession contributed significantly to improve investor confidence in the Chinese economy, and this might also be regarded as a productivity improvement in the export sector.

\section{Figure 6.2 The Swan Diagram for China}

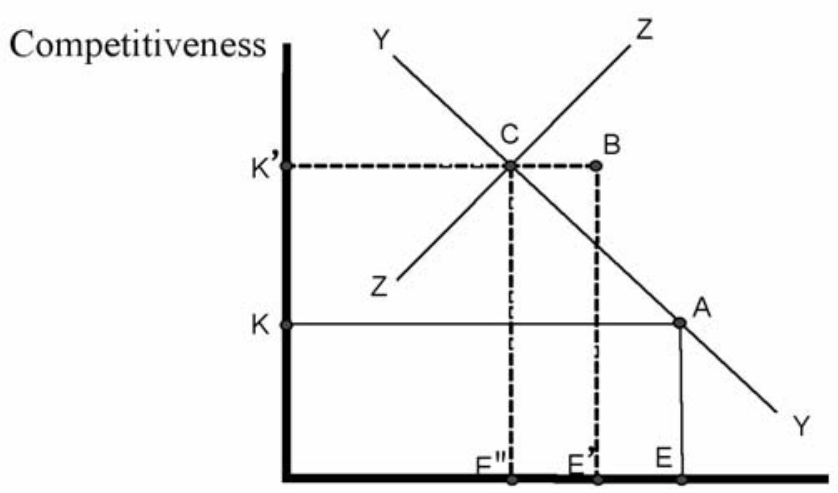

Real Expenditure

We start with competitiveness at $\mathrm{K}$. It is primarily determined by the real exchange rate. It increases to $\mathrm{K}^{\prime}$ from 2005 to 2007 owing to the productivity improvements just discussed, slightly offset by real appreciation owing to the change in the exchange rate regime in 2005. 
The horizontal axis shows total expenditure, both on consumption and on investment. We start at E. A decline in consumption (rise in savings) brings expenditure to the left, to $\mathrm{E}^{\prime}$. This would also result from a decline in investment. The line or curve YY is the "internal balance" line. Internal balance can be defined as the target level of spending on home-produced goods designed to avoid excessive inflation while maximising domestic output. The line shows various combinations of competitiveness and expenditure that would attain such internal balance.

In the diagram we start in internal balance at point $\mathrm{A}$. The improvement in competitiveness combined with the increase in saving (decline in expenditure) would bring the system to point B. But this is a situation of excess demand or potential inflation, so monetary policy in the form of controls on bank lending induces a reduction in expenditure, whether on lending for consumption or for investment, bringing expenditure down to $E^{\prime \prime}$ and the new equilibrium to $C$. If the current account had been in balance at $\mathrm{A}$ (hence savings were equal to investment, and expenditure equalled income), then it would be in surplus at $\mathrm{C}$.

A movement upwards along the YY curve improves the current account (greater surplus or reduced deficit). ${ }^{4}$

Thus, in China's case monetary policy has been targeted on the internal balance objective. This has been broadly achieved. In principle competitiveness could then be targeted on the current account objective. But competitiveness depends on much more than the nominal exchange rate, especially when it is a bilateral nominal rate. Since inflation both in China and its trading partners has not been high, perhaps there has not been a great difference between the (trade-weighted) nominal and the real exchange rate. But there is uncertainty about productivity changes in the tradeable sectors, and these cannot really be controlled. Thus policy could not easily regulate the movement from $\mathrm{K}$ to $\mathrm{K}^{\prime}$. Furthermore, the position of the internal balance line is also uncertain, and this line can move about in response to productivity changes in the non-tradeable sectors as well as structural changes and demand patterns in the economy.

It follows that the current account outcome is to some extent endogenous. Nevertheless, if the Chinese authorities were really determined to reduce or even eliminate the surplus they could presumably do so by sufficient nominal appreciation of the exchange rate. In order to maintain internal balance this would have to be associated with an easing of monetary policy leading to an increase in real expenditure. Just as variations and flexibility 
in monetary policy can roughly achieve and maintain internal balance, so a flexible exchange rate policy might be able to achieve and maintain an external balance objective. At the same time it needs to be remembered from the discussion above that the steep increase in the surplus from 2005 was not the result of deliberate shifts in exchange rate policy and was, indeed, not easily predictable. The main point, to be discussed below, is that exchange rate policy has not actually been targeted on external balance that is, on a current account objective. There have been other objectives.

\section{The motivations of China's policies}

The Chinese current account surpluses, and especially the big increases in them since 2005, are by-products of various developments, such as productivity improvements, but also of a variety of policies, including, of course - perhaps crucially - exchange rate policy. I shall now review these policies and their implications

The first policy is to maintain what I (following Meade) have called "internal balance" but is generally described as avoiding, or limiting, inflation, while adequately stimulating the economy through monetary policy. The monetary effects of exchange rate intervention must then be sterilised. This policy has been broadly successful, and the objective can hardly be disputed. ${ }^{5}$

The second policy is to intervene in the foreign exchange market so as to prevent excessive appreciation relative to the US dollar and, to an extent, stabilise the exchange rate. It is this policy that has been under continuous criticism in the US Congress and by some US economists. The policy is defended by Fan Gang, a Professor at the Chinese Academy of the Social Sciences, who gives a useful Chinese point of view that I paraphrase here (Fan, 2008).

The primary purpose of Chinese exchange rate policy is to maintain employment in export industries and, presumably also related employment in urban areas. Furthermore, large variations in the exchange rate would lead to speculation, and "China's immature and fragile financial system would not be able to bear those risks." In addition, the Chinese are opposed to large policy changes; they prefer to move policies in small steps. In any case it is not clear what the long-run equilibrium exchange rate should be, or what rate would finally satisfy US Congress. 
To summarise I would say that there have been two parts to Chinese exchange rate policy. The first part is "exchange rate protection", namely a policy designed to maintain profitability and employment in the export sector by means of undervaluation of the exchange rate ${ }^{6}$ The second part is to maintain a stable exchange rate, avoiding both a floating rate and sharp changes in a fixed-but-adjustable rate. US critics of Chinese exchange rate policy have frequently advocated either that the RMB should float or that there should be a steep once-for-all appreciation. Hence there have been two reasons for rejecting this advice.

Thirdly, for some years after the Asian crisis of 1997-98 China, as well as other East Asian countries, built up foreign exchange reserves deliberately as a form of self-insurance. It was provision against a balance of payments crisis so as avoid the need to call for rescue from the International Monetary Fund. But at least since 2006 China's reserves have been well above the level that seemed to be required.

The fourth set of policies explains why national savings by households and private and public corporations have been remarkably high. ${ }^{7}$ Relative to GDP aggregate savings are estimated to have been about 50 per cent of GDP in 2006. There are several relevant policies here. Household savings have been fairly high (about 15 per cent of GDP in 2006) owing to reduced social welfare arrangements, lack of pensions and the inadequacy of financial intermediation (see Woo, 2008). Enterprise savings have been exceptionally high (28 per cent of GDP in 2006) and have steadily increased owing to low wages and absence of payments of taxes or dividends to the government. ${ }^{8}$ The labour share of industrial value added in China during 2002-05 was less than 30 per cent (compared to a developed country average of over 65 per cent). Notwithstanding reported increases in average urban wages, unskilled worker wages have not increased much because of continuous massive labour inflows from the rural economy to urban centres. The outcome has thus been a persistent increase in company profits and thus savings.

The net result of the current account surplus and intervention in the foreign exchange market has been that by 2008 the central bank held nearly \$US2000 billion of reserves, a substantial part held in the form of US Treasuries. While some build-up of reserves made sense as a precaution against a balance of payments crisis, this amount of reserves can hardly be justified other than as a by-product of other policies which I have just 
described, policies which were either seen as desirable for other reasons, or could not easily be changed. ${ }^{9}$

It could thus be argued that the policies that led to such large current account surpluses and the build-up of massive foreign financial assets have not been in the Chinese interest. It surely cannot be in the long-term Chinese interest to accumulate vast amounts of dollar-denominated foreign assets (notably US Treasuries) earning a low return and very likely to lose real value relative to the prices of non-dollar goods owing to continued dollar depreciation. By 2007 the Chinese authorities seemed to be well aware of this, and planned to diversify their international investments. Also, probably China's national savings have been too high for a reason I have just mentioned above, namely that state-owned enterprises have used their profits for investment (or deposited them with banks) rather than paying more as dividends to the government. These extra government revenues could have been used to provide various much-needed government services to a population that, in part at least, is still quite poor.

On the other hand, it may have been rational to park temporarily a significant proportion of Chinese savings abroad until the public administration system had improved to allow more funds to be distributed to provincial governments for various social and infrastructure improvements. In addition, the capital market and banking system may also have needed improvements before some of the internationally accumulated funds could be efficiently invested domestically. Temporarily some of China's savings have thus been parked abroad, awaiting improvements in public sector management and in the capital market. I emphasize the word "temporarily". I have called this the "parking theory" (Corden, 2007).

On balance, this has probably not been a conscious motive for explaining the massive accumulation of reserves. The explanations given earlier are sufficient. The "parking theory" can be used not to explain the motivation of actual policies but rather to assess the net result of these policies. Has the net result actually been favourable for China? My suggestion is that it may indeed have been favourable, but only in the short run. With the accumulated reserves steadily growing the net result - the degree of "parking" - went too far, at least by 2007. 


\section{International implications of China's surplus and growth}

\section{How some countries' surpluses led to other countries' deficits}

For the world as a whole total current account surpluses must add up to other countries' deficits. These surpluses and deficits make up the "global imbalances" that have been of so much concern. The main concern has been that deficit countries, notably the country with the biggest deficit, the United States, cannot run such deficits indefinitely.

The world general equilibrium effects of the Chinese surplus cannot be analysed on their own. They must be aggregated with the effects of all the other surpluses (the main surplus countries having been China, Japan, Germany, the various oil exporters, and East Asian developing countries other than mainland China). In 2007 the Chinese surplus was 21.4 per cent of the total surplus of all the surplus countries. These were the "savings glut" countries, namely the countries where savings exceeded investment, even though in some cases the surpluses resulted from declines in investment rather than increases in savings. ${ }^{10}$

Treating these surpluses as exogenous - determined by a variety of factors influencing total savings and investment in each country, - they led to a fall in the world real interest rate. One should also take into account here the moderating effect on the fall of the world real interest rate of the exogenous increase in the US fiscal deficit (explained by political factors). This fall in the real rate of interest led in many countries, especially in the United States, to a credit boom and thus to increases in borrowing both for investment and for consumption. These increases in spending generated deficits in many countries, and possibly also reduced some surpluses. This was the endogenous effect of the decline in real interest rates that created the current account deficits to match the surpluses of the "savings glut" countries. ${ }^{11}$

It follows that through the world general equilibrium process involving a sharp decline in the world real interest rate the surplus of China was a part-cause of the deficit of the United States. But the exogenous increase in the politically-determined US fiscal deficit (or shift from surplus to deficit), as well as the exogenously-determined surpluses of savings glut countries other than China, also contributed to explaining the US deficit. 
It is worth noting that if US savings had not declined as much as they did, the US deficit might indeed have been avoided, or moderated. But the worldwide fall in interest rates and the credit boom would have been greater. Therefore, other countries would have had to borrow more and thus go into greater deficits. Alternatively, in the absence of such extra borrowing recessions would have developed in many countries, essentially because an excess of world savings was not absorbed sufficiently by extra private investment or government borrowing. Equilibrium would then be restored in a Keynesian process through falling incomes.

\section{Sectoral effects of the surpluses of the "savings- glut" countries}

What were the effects of the surpluses of China and the other savings-glut countries on various sections or interest groups in the deficit countries? For brevity I will refer specifically to the United States, as it has been the principal deficit country. Also, China has had the largest surplus since 2006, so it will represent all surplus countries. It is important to bear in mind that I am not concerned here with bilateral balances. Essentially the effects in the United States (and other deficit countries) come under two headings, namely trade effects and capital market effects.

Beginning with the trade effects of China's surplus, China exports mainly labour-intensive goods, and their prices have fallen relative to the general price level in the United States. Hence US producers of such goods have been adversely affected. The adverse effect on US import- competing producers, reflected in relatively lower wages and perhaps increased unemployment, has been the main effect that has carried political weight. It explains hostility to China ("China-bashing") in Congress, and the US pressure for appreciation of the RMB. The other side of this coin is that consumers of such goods in the US have benefited. As I will note below, US exporters to China have benefited from China's high growth (though not from its real productivity-adjusted depreciation). These exporters have probably been the main interest group that has acted as a counterweight to the "China-bashers".

The extraordinary growth of China, rather than just its current account surplus, has increased demand for many commodities, and thus benefited producers of oil and of commodities such as iron ore, copper and coal, which are exported by many countries, notably the oil exporters, but also countries such as Australia, Brazil and Chile. Exporters of various other 
products, especially capital goods and "high-tech" products, often coming from the United States or Germany, have also benefited. But Chinese growth has also harmed other countries, especially importers of oil.

The capital market effects in the United States of the Chinese surplus are usually not so clearly perceived. Lower interest rates benefit all borrowers, and especially the US government, which is a major borrower. Hence future US taxpayers benefit. On the other hand, Americans who are savers lose.

What about the value of the dollar relative to other developed country currencies, especially the euro and the yen? Since a large part of surplus countries' accumulation of foreign reserves (notably of China) has gone into dollar-denominated securities or investments of various kinds, especially US Treasuries, the surpluses have kept the dollar up, in spite of the growing US deficit. This also, of course, has had sectoral positive and negative effects.

Looking at the total effects of all these world-wide relative price changes, both positive and negative, one cannot really say clearly whether the net effects of the surpluses of China and other "savings glut" countries have been beneficial or not for the rest of the world. But one must certainly remind politicians and the public that cheaper imports from China have benefits for consumers, and that lower interest rates and readier availability of credit certainly have benefits for government Treasuries and private sector borrowers. Indeed a major beneficiary has been the Unites States Treasury and hence US taxpayers in the future.

It may be sufficient to make the point that when China, at the margin, exports goods to other countries in exchange for importing bonds and other financial instruments - especially from the United States - it is engaging in inter-temporal trade. There are likely to be gains from this kind of trade as from the usual trade in goods and services (Corden 2007).

\section{The causes of the current crisis. Is China to blame?}

It has been argued that the current world credit crisis has its origin in the excessive credit expansion in the United States and elsewhere, and in turn this has had its underlying origin in the high savings of the "savings glut" countries, which includes China. This credit expansion led to excessive leverage, the housing booms, and, in general, to irresponsible lending by financial intermediaries and to unwise or excessive borrowing by 
households, private equity, and (to a lesser extent) non-financial firms. While in the developing country debt crises of the nineteen eighties and nineties the blame was generally put on the borrowers, this time some would put the blame on the original lenders - i.e. the net savers, especially China.

In my view high savings need not - and should not - lead to crises. It is not unreasonable that in some countries savings exceed investment, for whatever reasons, and in others investment exceeds saving. There is an international capital market and its role is to intermediate between lenders and borrowers, just as such a market intermediates within countries. As expounded above, the mechanism of adjustment is the world real interest rate. Such an international market makes international inter-temporal trade possible, just as markets make possible ordinary trade in goods and services.

What, then, has gone wrong to create the disastrous world credit crisis, leading to worldwide recession?

Before the crisis, when world savings increased there seems to have been a lack of demand for funds from private corporations, or even governments, that wished to borrow and invest in order to increase physical or human capital, and where a reasonable return could be expected. In the United States, in the case of the private non-financial corporations this reluctance to borrow is explained by the rebound from the "dot com" bubble. In Latin American and East Asian countries other than China, it is explained by the rebound from earlier debt crises. Perhaps the financial intermediaries did not try hard enough to find such customers who were willing to borrow for investment with good prospects. Alternatively, one could simply regard these special explanations as pointing to an unfortunate coincidence. Just when world savings increased sharply sound investment opportunities had declined.

The result has been that much lending took place for more risky purposes, especially residential housing, and for consumption. This was the result of the so-called "search for yield". In the United States, in effect consumption rather than investment was mainly financed. Also, partially the gap in demand for funds was filled by the US fiscal deficit, which resulted from tax cuts and the need to finance the Iraq war. It might be recalled that John Maynard Keynes focused on the lack of perceived investment opportunities ("animal spirits") as a major cause of lack of aggregate demand. In this case world aggregate demand was maintained for some years, principally by increased US private consumption as well as, earlier, the US fiscal deficit, but perhaps at the cost of a later crisis. 
Thus there are several steps in the story. First there was the "savings glut" coming principally from Japan, China, the oil exporters, and Germany. Then there was the lack of sufficient demand for funds for fruitful investment for a variety of special reasons. Thus the high savings were not matched adequately by sound investment worldwide. Finally, there was the response in the world capital market, leading to "search for yield", excessive leverage, unwise lending, and so on. Hence China played a role in initiating this sad story, although - as I have noted earlier - in 2007 the Chinese surplus was only 21.4 per cent of the total surplus of all the surplus countries.

But there has been another factor explaining the crisis. This is simply that the large financial intermediation industry, including commercial banks, and prominently including investment banks, has failed in doing its job properly. The "fatal flaw" has been the invention and use of new financial instruments that have been poorly understood, and have created a serious information problem. Instead of the declining phase of a US housing bubble having an adverse financial impact that was confined to a limited number of US States, the manner of financing through securitisation of mortgages and their purchase worldwide created a worldwide financial crisis.

\section{Conclusion}

Finally, what has been the impact of China's growth, as distinct from its surplus, on the world economy? China's entry into the world economy has certainly been a major shock. And that is not just because it has generated exceptionally large current account surpluses since 2005. Even more important, it has created over a much longer period the shock of its massive growth acceleration.

Its government has chosen to be exceptionally outward looking in its approach. The Chinese emphasis has been on export expansion rather than just import substitution This approach has been consistently urged on developing countries by advisors from developed countries, and in this Chinese case has been notably fruitful. Surely the world has to adapt to China's growth and its dramatic transformation, welcoming the reduction of Chinese poverty, and enjoying the improved terms of trade that incidentally China has effectively bestowed on many of its trading partners. From Australia and many other countries it is buying more commodities, from the United States it is buying more government bonds 
(of which the US Treasury has been a massive supplier), and many other goods and services, and to many countries, notably the United States and in Europe, it is selling more labour-intensive goods. All these effects have improved its trading partners' terms of trade. Of course there are also losers. These include producers of labour-intensive goods in both developed and developing countries. But, in my view the Chinese shock is one that should be lived with, adapted to, and not resisted.

\section{References}

Anderson, J. (2008), 'China's Industrial Investment Boom and the Renminbi', in Goldstein, M. and N. R. Lardy (eds.), Debating China's Exchange Rate Policy, Washington, DC: Peterson Institute for International Economics.

Athukorala, P. (2009), 'The Rise of China and East Asian Export Performance: Is the Crowding out Fear Warranted?', The World Economy, vol. 32, pp. 234-266.

Athukorala, P. and N. Yamashita (2009), 'Global Production Sharing and Sino-US Trade Relations', China and World Economy, vo.17, pp. 39-56.

Bernanke, B. S. (2005), The Global Savings Glut and the U.S. Current Account Deficit, Washington, DC: Federal Reserve Board.

Corden, W. M. (1994) Economic Policy, Exchange Rates, and the International System. Oxford: Oxford University Press and Chicago: Chicago University Press.

Corden, W.M. (2007) 'Those Current Account Imbalances: A Sceptical View', The World Economy, vol.30: pp.363-82.

Fan, G. (2008), 'Renminbi Revaluation and US Dollar Depreciation', in Goldstein, M. and N. R. Lardy (eds.), Debating China's Exchange Rate Policy, Washington, DC: Peterson Institute for International Economics.

Goldstein, M. and N. R. Lardy (2005),'China's Revaluation Shows Size Really Matters', Financial Times, July 22.

Goldstein, M. and N. R. Lardy (eds.) (2008), Debating China's Exchange Rate Policy, Washington, DC: Peterson Institute for International Economics. 
Meade, J. E. (1951), The Balance of Payments, London: Oxford University Press.

Riedel, J. (2007), Jing J. and Jian G., How China Grows: Investment, Finance, and Reform, Princeton: Princeton University Press.

Siebert, H. (2007), 'China: Coming to Grips with New Global Player', The World Economy, vol.30: pp.893-922.

Swan, T.W. (1963), 'Longer-run Problems of the Balance of Payments', in Arndt, H.W. and W.M. Corden, (eds.), The Australian Economy: A Volume of Readings, Melbourne: Cheshire.

Wolf, M. (2008), Fixing Global Finance, Baltimore: Johns Hopkins University Press.

Woo, W. T. (2008), 'Understanding the Sources of Friction in U.S.-China Trade Relations: The Exchange Rate Debate Diverts Attention Away from Optimum Adjustment', Asian Economic Papers, vol.7: pp.65-99.

Yu, Y. (2007), 'Global Imbalances and China', The Australian Economic Review, vol.40: pp.3-23.

\section{Endnotes}

1. At the James Meade Centenary Meeting at the Bank of England on the $12^{\text {th }}$ July 2007 I presented a paper entitled "Exchange Rate Policies and the Global Imbalances". The present chapter, essentially completed in March 2009, is a substantially revised and expanded version of this 2007 paper. For excellent and comprehensive overviews of Chinese issues I have found particularly useful, Riedel, Jin and Gao (2007), Siebert (2007), Yu (2007), and Woo (2008). I am indebted to Jim Riedel for an understanding of Chinese macroeconomic processes, and to Prema-chandra Athukorala and David Vines for valuable comments on a draft of this chapter.

2. The best reference on US attitudes, and many aspects of the RMB issue, is Goldstein and Lardy (2008). The critical view of Chinese policy can be found particularly in the contribution in that volume by Michael Mussa, while a thorough review of US Congressional attitudes is in the contributions of Gary Clyde Hufbauer and Claire Brunel, and of Stephen S. Roach. For an earlier view that more RMB appreciation was desirable, see Goldstein and Lardy (2005).

3. A concise overview of China's "unbalanced" growth experience can be found in the contribution by Bert Hofman and Louis Kuijs in Goldstein and Lardy (2008).

4. In Fig.2 I have also drawn the curve $\mathrm{ZZ}$ which shows all the combinations of competitiveness and expenditure that would yield the same current account outcome as at $\mathrm{C}$. If that were the "external balance target" and competitiveness could be manipulated to achieve external balance, it would have meaning, in the same way as YY has meaning, because monetary policy is actually managed to attain internal balance. With the curve ZZ added I have drawn the complete Swan diagram. 
5. In a fast growing economy the demand for money has also been growing, and hence it has not been necessary to sterilise the monetary effects of exchange rate intervention completely, and indeed inflation has also not been zero. The inflation rate has been volatile. For a neat summary of money supply, inflation and sterilisation, see Siebert, (2007, p 903). On monetary policy, see also Eswar Prasad in Goldstein and Lardy (2008).

6. For extensive discussion of "exchange rate protection", see Corden (1994). It is closely related to "export-led growth".

7. Note the following complication. When total expenditure (consumption plus investment) is determined by the internal balance policy for any given competitiveness level (as is clear from Figure 2) the excess of savings over investment (equals excess of income over expenditure) is also given, and hence the current account surplus is given. Thus the ratio of savings to GDP and the ratio of investment to GDP cannot both be independently determined. In fact, both are influenced by the credit controls imposed on the banks, required for implementing the internal balance policy.

8. The figures come from Goldstein and Lardy (2008), p. 112.

9. This is how it looked in 2007. Now, in March 2009, when there has been a drastic fall in exports because of the world credit crisis and US recession, one cannot completely rule out the possibility that the reserves will be useful after all.

10. The term 'savings glut' originated in Bernanke (2005). Note also that there has been a massive shift of production bases from Japan, Korea and Taiwan (and earlier from Hong Kong) to China within global production networks. China's contribution to aggregate global surpluses has therefore been partly counterbalanced by declines in surpluses of these other surplus countries in the Asian region. See Athukorala and Yamashita (2009).

11. On the world general equilibrium process leading to the "global current account imbalances" see Corden (2007) and Wolf (2008, c 4). The latter explains clearly how the United States has been the "borrower and spender of last resort". 